\title{
PENGARUH MODEL PROBLEM BASED LEARNING BERBASIS ONLINE TERHADAP HASIL BELAJAR SISWA PADA KONSEP VIRUS
}

\author{
Sitti Aminah ${ }^{1}$ \\ Hilmi Hambali ${ }^{2}$ \\ Nurdiyanti $^{3^{*}}$ \\ 1,2,3Universitas Muhammadiyah Makassar, Makassar, Indonesia \\ aminahminah89@gmail.com ${ }^{1)}$ \\ hilmihambali@unismuh.ac.id ${ }^{2}$ \\ nurdiyanti@unismuh.ac.id ${ }^{\left.3^{*}\right)}$
}

\begin{abstract}
Abstrak
Penelitian ini merupakan jenis penelitian Quasi Eksperimen yang bertujuan untuk mengetahui pengaruh model Problem Based Learning (PBL) yang dilakukan secara online melalui hasil belajar peserta didik. Partisipan dalam penelitian ini terdiri dari 72 peserta didik, 36 yangpeserta didik sebagai kelas eksperimen dan 36 peserta didik sebagai kelas kontrol Penelitian ini terdiri dari beberapa tahap yaitu perancangan, pelaksanaan, observasi dan tes hasil belajar (evaluasi). Kelas eksperimen merupakan kelompok yang diajar dengan menggunakan model Problem Based Learning (PBL) secara dan Kelas kontrol diajar dengan menggunakan menggunakan metode konvensional. Beradasrkan hasil analisis data, mengungkapkan adanya peningkaan hasil belajar peserta didik yang lebih besar bagi kelompok yang diajar dengan model pembelajaran Problem Based Learning. Skor rata-rata yaitu 80,6\% dengan satandar deviasi yaitu 80 atau sekitar $40 \%$ peserta didik telah memenuhi kriteria ketuntasan minimal 75\%. Model pembelajaran Problem Based Learning berpengaruh terhadap hasil belajar siswa dapat juga diketahui dari selisih nilai rata-rata melalui Uji T kelas eksperimen yaitu 0,71 dan kelas kontrol yaitu sebesar 0,42. Dengan demikian dapat dinyatakan bahwa penguasaan peserta didik pada materi virus meningkat dari kategori rendah menjadi tinggi disamping itu peserta didik juga lebih disiplin aktif dan bertanggung jawab dalam mengikuti kegiaan pembelajaran.
\end{abstract}

Kata Kunci: PBL, Biologi, Virus, Online, Hasil Belajar

Published by:

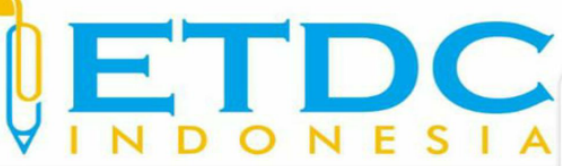

Copyright (C) 2021 The Author (s)

This article is licensed under CC BY 4.0 License

(cc) $\mathrm{BY}$ 


\section{PENGARUH MODEL PROBLEM BASED LEARNING BERBASIS ONLINE TERHADAP HASIL BELAJAR SISWA PADA KONSEP VIRUS}

\section{Pendahuluan}

Pendidikan merupakan kegiatan yang terencana yang bertujuan untuk membuat proses pembelajaran agar peserta didik berperan aktif dalam bekajar dan mengembangkan potensi yang dimilikinya. pendidikan di Indonesia bertujuan untuk mencerdaskan kehidupan bangsa dan mengembangkan manusia seutuhnya, yaitu manusia yang beriman serta bertaqwa kepada Tuhan YME serta memiliki budi pekerti luhur, pengetahuan dan keterampilan, kesehatan jasmani dan juga rohani, kepribadian yang mandiri serta memiliki rasa tanggung jawab terhadapmasyarakat dan bangsa (Sisdiknas, 2003).

Proses pencapaian suatu tujuan dalam bidang pendidikan pasti ada kendala yang menghalangi pencapaian tujuan itu. Masalah yang timbul pada poses pembelajaran misalnya, kurangnya minat dan partisipasi peserta didik dalam mengikuti pemebelajaran serta kurangnya kreativitas guru dalam menerapkan model pembelajaran sehingga hasil belajar peserta didik relatif lebih rendah.

Pembelajaran pada dasarnya yaitu usaha seorang pendidik untuk membelajarkan siswanya dengan cara membuat siswa melakukan interaksi dengan sumber belajar lainnya, agar dapat mencapai tujuan pembelajaran (Trianto, 2010). Oleh karena itu, dalam proses pembelajaran terjadi interaksi antara guru dengan peserta didik, dimana terjadi komunikasi yang terarah antar keduanya menuju pencapaian target pembelajaran yang telah dirumuskan sebelumnya. Inti dari proses pembelajaran yaitu rangkaian aktivitas belajar siswa dalam meningkatkan kemampuan dan kualitas peserta didik.

Berdasarkan hasil observasi peneliti di SMA Negeri 2 Enrekang, terdapat beragam masalah yang dihadapi dalam proses pembelajaran sehingga menghambat pencapaian tujian pembelajaran, salah satunya yaitu peserta didik kurang aktif berpartisipasi dalam proses pembelajaran, rendahnya minat dan motivasi peserta didik untuk belajar. Hal ini tentunya berdampak pada hasil belajar peserta didik yang relatif lebih rendah, dimana hanya sekitar $40 \%$ peserta didik yang dapat mencapai nilai KKM biologi yang telah diterapkan. Rendahnya hasil belajar disebabkan karena kemampuan peserta didik masih terbatas pada hafalan dan peserta didik mengalami kesulitan jika dihadapkan pada soal yang membutuhkan analisis dan pemahaman. Berdasarkan permasalahan ini, maka sangat perlu diterapkan sebuah model pembelajaran yang mampu mengatasi permasalahan tersebut, yaitu dengan menggunakan 
pembelajaran berdasarkan masalah atau Problem Based Learning (PBL).

Problem Based Learning atau PBL merupakan sebuah model pembelajaran yang penyajian materinya berorientasi pada masalah yang dikembangkan berdasarkan tujuan pembelajaran, agar siswa memperoleh pengetahuan yang membuat mereka mampu dalam mengatasi suatu permsalahan dan memiliki kemampuan bekerja dalam tim. Pembelajaran yang berorientasi pada masalah dapat membantu siswa mengembangkan kemampuan pembecahan masalah, berpikir kritis, dan juga keterampilan intelektualnya. (Desriyanti \& Lazulva, 2016).

Menerapkan model pembelajaran Problem Based Learning (PBL) dalam pembelajaran biologi, dapat membuat peserta didik mampu berpikir tingkat tinggi. Peserta didik harus belajar dalam memecahkan masalah untuk mengembangkan kemampuannya dalam menganalisis dan mengolah informasi yang diperolehnya.

Lebih dari itu, siswa pada era saat ini telah menggunakan teknologi dalam kehidupan sehari-hari, seperti smartphone atapun PC yang dapat tersambung ke internet. Kecanggihan tegnologi di era ini, dapat dimanfaatkan oleh para pendidik sebagai fasilitas dalam mendukung proses pembelajaran, khususnya situasi saat ini yaitu pandemik virus corona yang menyerang berbagai negara, termasuk Indonesia. Kasus pandemi Covid-19 semakin meningkat tiap harinya, sehingga pembelajaran online menjadi solusi yang dapat digunakan satu-satunya agar aktifitas pendidikan dapat terus berlanjut.

Pembelajaran online dilakukan dengan memanfaatkan jaringan internet yang dapat menghubungkan seseorang yang satu dengan yang lainnya walaupun jarak jauh. Pembelajaran yang dilaksanakan secara online, menggunakan sistem pembelajaran jarak jauh, dimana, kegiatan pembelajaran tidak dilakukan secara tatap muka. Pembelajaran dilakukan melalui berbagai jenis media pembelajaran (Mona, 2020).

Pembelajaran secara online dengan menggunakan berbagai jenis model pembelajaran telah diterapkan diberbagai sekolah. Penerapan model PBL yang dilakukan secara online memberikan dampak yang baik terhadap hasil belajar dan juga memberikan pengalaman baru pada seluruh siswa. (Wayan Suryanto, 2020).

Berdasarkan uraian permasalahan pendidikan, maka tujuan peneltian ini yaitu untuk mengetahui pengaruh model pembelajaran Problem Based Learning (PBL) melalui pembelajaran online terhadap hasil belajar biologi konsep Virus pada kelas X SMA Negeri 2 Enrekang.

\section{Metode Penelitian}

Jenis penelitian yang digunakan dalam penelitian ini yaitu Quasi Eksperimen 
(eksperimen semu) dengan menggunakan desain penelitian Non Equivalent Pretest Posttest Control Group Design. Prosedur penelitian meliputi beberapa tahap yairu: 1) tahap observasi dengan mengamati proses belajar, 2) menentukan populasi dan sampel, 3) menyusun perangkat pembelajaran (RPP), 4) menyusun instrument penelitian berupa Pilihan ganda 30 nomor, dan 5) melaksanakan uji validitas perangkat pembelajaran.

Penelitian ini dilaksanakan di SMA Negeri 2 Enrekang yang berlokasi di Jalan Jendral Sudirman Galonta, Kec. Enrekang, Kab. Enrekang, Sulawesi Selatan. Teknik pengembailan sampel dalam penelitian ini, menggunakan teknik purposive sampling. Sampel dalam penelitian ini adalah peserta didik kelas X MIA 2 sebagai kelompok eksperimen dan X MIA 3 sebagai kelompok kontrol dengan jumlah peserta didik yang digunakan sebagai sampel sebanyak 72 siswa di SMA Negeri 2 Enrekang.

Variabel yang diukur dalam penelitian yaitu variabel bebas dan terikat. Adapun variabel bebas adalah model Problem Based Learning dan variabel terikat adalah hasil belajar siswa pada konsep vírus. Instrumen yang akan digunakan dalam penelitian ini adalah tes hasil belajar kognitif peserta didik berupa lembar soal. Bentuk soal yang diberikan berupa soal pilihan ganda sebanyak 30 butir. Nilai hasil belajar diambil sebanyak dua kali, yaitu pada saat sebelum rangkaian kegiatan pembelajaran (pre test) dan setelah proses pembelajaran (post test).

Teknik analisis data yang digunakan pada penelitian ini yaitu analisis statistik deskriptif dan statistik inferensial pada data hasil Pre-test dan Post-test kelompok eksperimen dan kelompok kontrol.

\section{Hasil dan Pembahasan}

\subsection{Analisis Statistik Desktiptif}

a. Desktipsi Hasil Belajar Peserta Didik

Berikut merupakan hasil analisis deskriptif dari hasil belajar biologi peserta didik pada konsep Virus yang diperoleh dari kedua sampel kelas yaitu kelas ekperimen dan kelas kontrol yang disajikan dalam Tabel 1 berikut:

Tabel 1. Peserta Didik Kelas Ekperimen Dan Kelas Kontrol

\begin{tabular}{lcccc}
\hline \multirow{2}{*}{ Statistik } & \multicolumn{2}{c}{ Kelas Eksperimen } & \multicolumn{2}{c}{ Kelas Kontrol } \\
\cline { 2 - 5 } & Pre-Test & Post-Test & Pre-Test & Post-Test \\
\hline Sampel & 36 & 36 & 36 & 36 \\
Mean & 39,28 & 83,56 & 32,36 & 62,39 \\
SD & 14,702 & 10,673 & 11,917 & 11,960 \\
Varians & 216,136 & 113,911 & 142,009 & 143,044 \\
\hline
\end{tabular}


Beradasarkan data pada Tabel 1 dapat dilihat nilai rata-rata (mean) kelompok eksperimen dan kelompok kontrol. Kelompok eksperimen memperoleh nilai rata-rata sebesar 39,28 pada Pre-Test dan sebesar 83,56 pada Post-Test. Kemudian pada kelompok kontrol, nilai rata-rata Pre-test yang diperoleh sebesar 32,36 dan post test sebesar 62,39. Hal ini sejalan dengan penelitian yang dilakukan oleh Yance (2013) yaitu hasil belajar peserta didik meningkat setelah penerapan model pembelajaran PBL.Model problem based learning berpengaruh positif terhadap hasil belajar kongnitif siswa (Fitri, 2019). Sementara pengkategorian data skor hasil belajar peserta didik pada konseo virus pada, dapat dilihat Tabel 2 sebagai berikut :

Tabel 2. Kategorisasi Hasil Belajar Peserta didik

\begin{tabular}{llcccc}
\hline Interyal & \multirow{2}{*}{ Kategori } & \multicolumn{2}{c}{ Kelas Eksperimen (\%) } & \multicolumn{2}{c}{ Kelas Kontrol (\%) } \\
\cline { 3 - 6 } & & Pre-Test & Post-Test & Pre-Test & Post-Test \\
\hline $\mathbf{9 3 - 1 0 0}$ & Baik Sekali & 0 & 22,2 & 0 & 0 \\
$\mathbf{8 4 - 9 2}$ & Baik & 0 & 27,8 & 0 & 0 \\
$\mathbf{7 5 - 8 3}$ & Cukun & 0 & 30,6 & 0 & 19,4 \\
$\mathbf{6 7 - 7 4}$ & Kurang & 5,6 & 11,1 & 0 & 25 \\
$\mathbf{6 6}$ & Sangat Kurang & 94,4 & 0,08 & 100 & 55,6 \\
\hline
\end{tabular}

Dapat dilihat pada Tabel 2 jumlah peserta didik pada kelas eksperimen yang memperoleh hasil belajar yang berada pada kategori baik sekali yaitu sebesar 22,2\%, sementara pada kelompok kontrol, tidak terdapat peserta didik yang memperoleh hasil belajar yang berada pada kategori baik sekali.

b. Uji N-Gain

Uji N-gain berguna unuk mengetahui perbandingan peningkatan antara nilai pre-test dengan nilai post-test pada kelompok eksperimen dan kelompok kontrol. Adapun hasil perhitungan N-gain hasil belajar peserta didik adalah pada Tabel 3 sebagai berikut

Tabel 3 Nilai Uji N-gain

\begin{tabular}{lcc}
\hline Kelas & Nilai Rata-Rata & Kategori \\
\hline Eksperimen & 0,71 & Tinggi \\
Kontrol & 0,42 & Sedang
\end{tabular}

Berdasarkan data pada Tabel 3 terlihat bahwa rata-rata nilai uji N-gain hasil belajar peserta didik pada kelompok eksperimen sebesar 0,71 yang dikategorikan tinggi, sedangkan untuk kelompok kontrol sebesar 0,42 yang berada pada kategori sedang.

\subsection{Analisis Inferensial}

Sebelum Uji hipotesis, dilakukan uji pra syarat yaitu uji normalitas dan homogenitas. Beradasarkan hasil analisis, Uji normalitas menggunakan SPSS Statistic 25 dengan uji 
Normality Test (Kolmogorov-Smirnov) dan uji homogenitas dua buah variabel menggunakan uji Homogenity Of Variance Test dengan bantuan SPSS 25. Beradasrkan analisis, data penelitian terdistribusi normal dan homogen.

Selanjutnya dilakukan uji hipotesis dengan menggunakan Uji N-Gain Independen Sampel T-test pada SPSS 25. Beradasrkan hasil uji Uji N-Gain Independen Sampel T-tes kelas eksperimen dan kelas kontrol diperoleh Nilai Sig (2-tailed) sebesar 0,000. Nilai tersebut lebih kecil dari nilai signifikansi (Sig.) 0,05 dapat disimpulkan bahwa ada perbedaan efekifitas yang signifikan (nyata) antara penggunaan model pembelajaran Problem Based Learning (PBL) secara online dengan metode konvensional secara online untuk meningkatkan hasil belajar Biologi peserta didik konsep virus pada kelas X MIA SMA Negeri 2 Enrekang. Penarapan model problem-based learning lebih efektif dibanding menggunakan pembelajaran konvensional (Desy, 2016).

\section{Kesimpulan}

\subsection{Kseimpulan}

Berdasarkan hasil penelitian, maka dapat disimpulkan bahwa penerapan model Problem Based Learning (PBL) secara online memiliki pengaruh positif terhadap hasil belajar peserta didik dibanding pembelajaran online dilakukan dengan metode ceramah saja. Berdasarkan data yang dipeorleh, rata-rata hasil belajar pada kelompok eksperimen lebih tinggi dibdandingkan dengan kelompok Kontrol. Pada Uji hipotesis, diperoleh Nilai Sig (2-tailed) adalah sebesar $0,000<0,05$. Maka dengan demikian dapat disimpulkan bahwa ada perbedaan yang signifikan (nyata) antara penggunaan model Problem Based Learning (PBL) dan model konvensional secara online hasil belajar Biologi peserta didik konsep virus pada peserta didik kelas X SMA Negeri 2 Enrekang.

\subsection{Saran}

Peneliti selanjutnya diharapkan agar mengkaji lebih dalam terkait efektivitas penerapan Problem Pased Learning yang diterapkan secara online, terutan mengungkap berbagai faktor yang dapat menghambat implementasi Problem Based Learning yang dilakukan secara online

\section{DAFTAR PUSTAKA}

Afandi, M. S. P., Chamalah, E., \& Oktarina Puspita Wardani, S. P. (2013). Model dan Metode Pembelajaran. Semarang: Unissula.

Amrullah, Arfan. 2016. Pengaruh Model Pembelajaran Problem Based Learning terhadapa 
Hasil Belajar Biologi Siswa Pada Konsep Fungi QuasiEksperimenSMA87jakarta.http://repository.uinjkt.ac.id/dspace/bitstream/12 3456789/31927/3/ARFAN\%20AMRULLAH-FITK.pdf.

Asih, Dwijowati Saputri \& Selfy febriani. 2017. pengaruh model Problem Based Learning (PBL) terhadap kemampuan pemecahan masalah peserta didik pada materi pencemaran lingkungan kelas X MIA. BIOSFER Jurnal Tadris Pendidikan Biologi Vol. 8 no. 1 (2017) 40-52 p-ISSN : 2086-5945 e-ISSN : 2580-4960Juli 2017.http://ejournal.radenintan.ac.id/index.php/biosfer/index

Astika, I. K. U., Suma, I. K., \& Suastra, I. W. (2013). Pengaruh Model Pembelajaran Berbasis Masalah terhadap Sikap Ilmiah dan Keterampilan Berpikir Kritis. E-Journal Program Pascasarjana Universitas Pendidikan Ganesha Program Studi IPA, 3(2), 1-10.

Dayeni, Fitri. Sri Irawati \& Yennita. Upaya Meningkatkan Motivasi dan Hasil Belajar Siswa Melalui Model Problem Based Learning. Diklabio: Jurnal Pendidikan dan Pembelajaran Biologi 1(1): 29-36 (2017) ISSN 2598-9669.

Desriyanti, R. D., \& Lazulva, L. (2016). Penerapan Problem Based Learning pada Pembelajaran Konsep Hidrolisi Garam untuk Meningkatkan Hasil Belajar Siswa. JTK (Jurnal Tadris Kimiya), 1(2), 70-78.

Hikmayanti, I., Saehana, S., \& Muslimin, M. (2016). Pengaruh Model Problem Based Learning Menggunakan Simulasi terhadap Hasil Belajar Siswa pada Materi Gerak Lurus Kelas VII MTs Bou. JPFT (Jurnal Pendidikan Fisika Tadulako Online), 3(3), 58-61.

Ibrahim, A. S. E. (2017). Pengaruh Model Problem Based Learning terhadap Hasil Belajar Mata Pelajaran Ekonomi pada Siswa SMA Negeri 1 Palu. Katalogis, 5(4), 9-20.

Kemendikbud. (2013). Panduan Penilaian oleh Pendidik dan Satuan Pendidikan untuk Sekolah Menengah Atas. Jakarta: Direktorat Pembinaan Sekolah Menengah Atas.

Kemendikbud. (2017). Panduan Penilaian oleh Pendidik dan Satuan Pendidikan untuk Sekolah Menengah Atas. Jakarta: Direktorat Pembinaan Sekolah Menengah Atas.

Krisnadi Iwan, dkk. 2020. Analisis Efektifitas Pembelajaran Daring (online) untuk Siswa SMK Negeri 8 Kota Tangerang pada Saat Pandemi COVID-19. Jurnal Ilmiah Pendidikan. Vol 1. No 2.

Maisaroh, M., \& Rostrieningsih, R. (2010). Peningkatan Hasil Belajar Siswa dengan Menggunakan Metode Pembelajaran Active Learning Tipe Quiz Team pada Mata Pelajaran Keterampilan Dasar Komunikasi Di SMK Negeri 1 Bogor. Jurnal Ekonomi dan Pendidikan, 7(2), 157-171.

Mona, N. (2020). Konsep isolosi dalam jaringan sosial untuk meminimalisasi efek contagious (kasus penyebarab virus corona di indonesia) . jurnal sosial humaniora terapan universitas indonesia, 2(2).

Nadiya, I. (2017). Pengaruh Model Pembelajaran Problem Based Learning (PBL) terhadap Penguasaan Konsep Siswa pada Materi Sistem Saraf: Penelitian pada Siswa Kelas XI 
SMAN 1 Kawali Kab. Ciamis (Doctoral dissertation, UIN Sunan Gunung Djati Bandung).

Nasir, M., Wagino, W., \& Pasaribu, M. (2017). Improvement of Student Learning Achievements and Activities in Learning Mechanics Using Tools Using Model Problem Based Learning Class X Technique Light Vehicles 2 Smk N 1 Pariaman. Invotek: Jurnal Inovasi Vokasional dan Teknologi, 17(2), 54-60.

Noveandini, R., \& Wulandsri, m. S. (2010). Pemanfaatan median pembelajaran secara online (E-learning) bagi wanita karir dalam upaya meningkatkan efektivitas dan fleksibilitas pemantauan kegiatan kerja belajar anak siswa/i sekolah dasar. In seminar nasional aplikasi Teknologi informasi ( SNATI).

Nguyen Tuan. 2015. The Effectiveness Of Online Learning : Beyond Ni Significant Difference and Future Horizons. Merlot Journal Of Online Learning and Teaching. Vol 11, No, June 2015.

Pranoto, P., \& Santosa, S. (2014). Perbandingan Model Pembelajaran Problem Based Learning dengan Guided Discovery Learning terhadap Keaktifan Siswa Kelas X SMA Negeri 1 Ngawi Tahun Pelajaran 2013. Bioedukasi UNS, 10(1), 18-22.

Pryatna M. dkk, 2018. Penggunaan Sosial Media WhatsApp dan Pengaruhnya Terhadap Disiplin Belajar Peserta Didik Pada Mata Pelajaran Pendidikan Agama Islam. Jurnal Pendidikan Islam. Vol 07, No 01.

Sanjaya, W. (2006). Pembelajaran Berorientasi Standar Proses Pendidikan. Jakarta: Kencana Prenada Media.

Sri, Fitri, Agading. 2019. Pengaruh Model Pembelajaran Problem Based Learning (PBL) Terhadap Hasil Belajar Siswa pada Materi Virus Kelas X di SMA Negeri 2 Rambang Kuang. Universitas Muhammadiyah Palembang.

Sugiono, 2018. Metode Penelitian Pendidikan (PendekatanKuantitatif,Kualitatif, dan R\&D). Bandung : ALFABETA.

Sumartono, S., \& Normalina, N. (2015). Motivasi dan Hasil Belajar Siswa dalam Pembelajaran Matematika dengan Menggunakan Model Pembelajaran Kooperatif Tipe Scramble Di SMP. EDU-MAT, 3(1), 9-18.

Yance R. D, Ramli E, Mufir F. 2013. Pengaruh penerapan model Problem Based Learning (PBL) terhadap hasil belajar fisika siswa kelas XI IPA SMA Negeri 1 Batipuh Kabupaten Tanah Datar. Pillar Of Phyisics Education Vol 1, 48-54.

Yanuarti, A., \& Sobandi, A. (2016). Upaya Meningkatkan Hasil Belajar Siswa Melalui Penerapan Model Pembelajaran Quantum Teaching. Jurnal Pendidikan Manajemen Perkantoran, 1(1), 11-18 